\title{
TRENDS IN EVOLUTION OF SIGNAL INTERPRETATION AS PRECURSORS OF THE ORIGIN OF HUMAN LANGUAGE
}

\author{
BURLAK SVETLANA ${ }^{* 1}$ \\ *Corresponding Author: svetlana.burlak@bk.ru \\ ${ }^{1}$ Institute of Oriental Studies, RAS, Moscow, Russia
}

\begin{abstract}
There are several major trends in signal interpretation in animal communication systems: from mere behaviour to specialized signals, from emotional signals to referential ones, from innate signals to arbitrary symbols; all of them are essential for the emergence of human language because human language is specialized and based on referential signs of symbolic nature. A need for a constant increase of the amount of symbols gave rise to phonology, syntax and other language-specific features. Focusing on signal interpretation makes it possible to construct a consistent model of language origin. It also provides a solution to the problem of honest communication emergence as well as a solution to the problem of gradual change.
\end{abstract}

\section{Studies of animal communication systems}

The communicative system of our non-human ancestors was an animal communication system, thus subject to the regularities that determine the evolution of such systems. Nevertheless, most language evolution models pay little attention to animal communication, and almost completely neglect trends that can be observed in its evolution.

Most scholars who study animal communication aim to identify the prerequisites of different aspects of human language capacity, as well as analogies between some traits in animal communication and human language. Thus, the ability to count is regarded as a prerequisite for recursion, preverbal concepts provide a basis for the development of language signs, birdsong syntax is considered as analogous to human language syntax (Okanoya 2002; Hurford 2012), geladas' lip-smacking is considered a precursor to speech (Bergman, 2013), and so on. In many works, animal communication systems are compared to human language in order to determine the distinctive features between the two (Hockett, 1960; Pinker \& Jackendoff, 2008). For instance, N. Chomsky claims that the syntax (or, more specifically, the faculty of recursion) must have 
played a cornerstone role in the language origin (Chomsky, 2002; Hauser et al., 2014), and shows that non-human animals are incapable of acquiring a recursion-based grammar (Hauser et al., 2002). T. Deacon (1998) claims that Homo sapiens is the only "symbolic species" (though he assumes that trained chimpanzees are capable of symbolization).

One author who pays more attention to animal communication systems is D. Bickerton (2009). According to his point of view, the human language emerged as a guidance system, like those that exist in several eusocial hymenopteran species (honey bees and some species of ants (Reznikova, 2017)), and its main goal was to convey information about remote objects. Nevertheless, even though D. Bickerton understands the importance of the evolutionary approach to the understanding of the emergence of human language, he says nothing about the evolutionary tendencies in animal communication. This creates a paradoxical situation: while the evolution of human body, its parts and organs is studied in details (see, e.g. Shubin (2008)), our communication system would appear to have sprung up out of nowhere, as if the body of our ancestors evolved and their communication system did not. This is, certainly, not the case. Communication systems of our ancestors did evolve as well, and there are several trends in their evolution that must have been essential for the emergence of human language.

K. Gibson (2010) pays attention to convergent evolution, because similar traits can evolve in very distantly related species in response to similar environments. She suggests that language-evolution process was jump-started by tool-assisted omnivorous extractive foraging.

Some authors present computational models of evolution of communication. For instance, T. Scott-Phillips (2010) shows that only that communicative system is evolutionary stable that is geared to maximize payoffs of both signaler and receiver. In his paper, however, nothing is said about evolutionary trends directional changes of animal communication systems of one type to animal communication systems of another type.

Only a few authors, like I. Pepperberg (2012), mention a trend in animal communication system evolution in this respect (namely, the trend from innate to learned birdsong acquisition).

In this paper, we try to outline several patterns in the evolution of animal communication systems that may have played a role in human language evolution. 


\section{From Mere Behaviour to Signal}

It is important to note that the properties of a communication system depend greatly on the way of life of the species (cf. Reznikova, 2017): only the most necessary things for fitness are encoded in signals. That way, signalling is an advantageous strategy in social species, but disadvantageous in solitary ones.

One of the features that oppose most animal communication systems to human language is that signals produced by animals are unintentional, and are not "designed from the beginning to communicate with. Rather they are modifications or stylizations or amplifications of things animals would do anyway" (Bickerton, 2009: 17). W. T. Fitch notes that, in animal communication, there are two levels of intentionality: "At the most basic level, so-called zero-order intentionality, the signaller has no intention psychologically, but the signal has nonetheless evolved to convey a message", while at the "first-order intentionality, a link between a mental representation and reality justifies our psychological interpretation of the signal, but implies no specific intent to inform another" (Fitch, 2010: 190).

It is important to emphasize that consciousness and intentionality are not necessary for the emergence of communication, only detectors are needed. An individual able to detect features of environment is eo ipso able to detect certain elements of conspecifics' appearance and behaviour; so when it is useful for some intentions (or observations) of an individual to be detected by conspecifics, the natural selection favours them to become more easily detectable. A good example is provided by two closely related species of toadhead agamas, reticulated toadhead agama Phrynocephalus reticulatus and sunwatcher toadhead agama Phrynocephalus helioscopus (Rogovin, 1991). For both species, it is important that a male does not spend its sperm on an already fecundated female. A female Ph. reticulatus may either bite a male in such case or run away. Conversely, for a female Ph. helioscopus, it is a bad strategy, because $P h$. helioscopus have stronger jaws and are more purposeful, so a bite would be more dangerous for a male, and an attempt to run away is likely to fail. So, a female $P h$. helioscopus produces a kind of press-up pantomime moving its body up and down, and a male ceases to pursue the female upon seeing this pantomime.

The "etymology" of this signal is quite transparent: it comes from common movements of two intentions, to bite and to run away, each of which can be seen in Ph. reticulatus behaviour. If a female Ph. reticulatus feels hesitation and spends a second or two choosing the behavioural program, we can see even both movements. However, there is a very important difference: in Ph. reticulatus, 
they are merely movements, fluent and blurred, while in Ph. helioscopus, they function as a signal, they are longer, more distinct and more noticeable, being optimized for identification by male's detectors. Toadhead agamas' brain is very small, so signal movements cannot be blurred and fuzzy.

In ancestor toadhead agamas, natural selection favoured either the set "strong jaws + strength of purpose + signal" or the set "weaker jaws + lack of purposefulness + no signal". The males that failed to guess that a female with strong jaws had been already fecundated were either injured more seriously, or spent their sperm in vain in case they overtook the female and thus had less opportunity to produce offspring in both situations. The males of the species that is not so purposeful and does not have strong jaws can manage without guessing females' intentions since they would not be seriously injured in case a female chose to bite and most probably would not overtake a female that chose to run away.

Therefore, the main driving force for signals to develop is not the need to communicate something to somebody but the need to recognize something about a conspecific in order to minimize harm on oneself. For animals that are obliged to live close by their conspecifics, it is very important. It does not matter whether an individual producing a signal is even aware that the signal is produced, - if such signals help animals to minimize harm their conspecifics may inflict on them, they will be favoured by natural selection.

This is the solution of the problem of honest communication emergence (cf. Maynard Smith \& Harper 2003): if individuals are selected not to transmit information but rather to understand it, than those that would notice only honest signals would never be deceived, would be able to choose a more appropriate behavioural program and produce more offspring as a consequence. This is also a solution for the problem of gradual change: what use is half a language? When we assume that the natural selection favours not production but interpretation, then any minor feature of behaviour that may give a cue to the perceiving individual would be useful because it would help the individual to obtain some information and thus to choose a more appropriate behavioural program.

For individuals whose state, mood and intentions are easily recognized by conspecifics, it is also of some use: e.g., if a conspecific notices the individual's aggressive mood, it may help avoid a conflict and avoid injures; if conspecifics of an individual are able to get information about food sources from it, such individual will have more satiated and healthy mates to transmit its genes with; an individual that will usually alarm its conspecifics in case of danger will have wider choice of potential mates. It is very important to have a wide choice 
because the genes of a potential mate need to be not "the best", but the most compatible with the genes of mating individual (Markov \& Kulikov, 2006; Promislow et al., 1998).

That way, it is not a mere chance that most signals produced by animals are not conscious and not deliberate: natural selection does not favour the production of signals, but their interpretation. The most ancient trend in animal communication evolution is emancipating certain elements of appearance and behaviour from needs of everyday routine and tuning them to be optimally recognized by brain detectors. Sound symbols of the human language may have also evolved in such a way, without any purpose or intention to make new signals.

\section{From Emotional Signals to Referential Ones}

The second important trend in evolution of animal communication is the evolution of referential signals from emotional ones. Emotional signals express the emotional state of an individual and are in factual connection to their objects. However, there are situations in which it is more useful to know not the emotion itself but the cause of it. The best example here is provided by alarm calls in vervet monkeys. Each call type elicits a different response (Seyfarth \& Cheney 2012), and if a monkey that had heard a leopard alarm stayed on the ground looking at the sky (as if it had heard an eagle alarm), it would be eaten up; the same will happen to a monkey that mistook an eagle alarm for a leopard one. Therefore, natural selection favours the most precise discrimination between different types of alarm calls and production of the most distinct calls. There are several species having referential signals, namely: vervet monkeys (Cheney \& Seyfarth, 1990; Seyfarth \& Cheney, 2012; Hauser, 1996: 645-646), ground squirrels (Leger et al., 1980), marmots (Blumstein, 2007), meerkats (Manser \& Bell, 2004; Hollén \& Manser, 2006), ring-tailed lemurs (Macedonia, 1990; Pereira \& Macedonia, 1991), Gunnison's prairie dogs (Slobodchikoff et al., 1991) and even chicken (Evans \& Evans, 1999). There is a hypothesis according to which referential signals may have a very precise meaning, for example, denoting not only the type of object but also its colour (Slobodchikoff et al., 2009).

There is a crucial difference between emotional and referential signals. Emotional signals may vary along a continuum because the degree of feeling is continuous, while referential signals are discrete because there is no intermediary between, say, an eagle and a leopard. Humans use signals of both 
types: our morphemes, words and sentences are referential while elements of nonverbal communication are emotional signals.

In some works, referential signals are considered an intermediary stage on the way from an animal communication system to human language: at first, there was a few referential signals, as in vervet monkeys, then they grew in number (Bickerton, 2003: 79). However, this is certainly not the case for two reasons. First, human language is an open system, we are capable of producing an infinite number of sentences and even of words. On the contrary, vervet monkeys' referential signals are innate, and such a system can never become an infinite one. Second, apes, which are the closest relatives of humans, do not have referential alarm calls. Thus, in human clade, the ability to use referential signals must have been formed de novo (and that is why it is not very similar to what we see in vervet monkeys).

Evolution from emotional signals to referential ones can be traced in ground squirrels. Evolutionary primitive ground squirrels have sounds reflecting the degree of their fear: when fear is great, they produce whistles, when fear is weak they produce trills, and in intermediary cases intermediary sounds break from them. In evolutionary more advanced species, alarm calls become specialized: whistles break from the individuals noticing a flying raptor and chatter-chat calls (homologous to trill) are elicited by terrestrial predators, and no intermediary variant exists. The correlation between the specialization of a species and the number of specialized signals it uses can be seen in martmots (see Blumstein, 2007: 373).

Sometimes it is not easy to determine whether a signal is emotional or referential. Food calls in chimpanzees (Slocombe \& Zuberbühler, 2005) may refer to outer world objects, but they may be emotional signals as well reflecting not the outer world objects themselves but merely the emotions of vocalizing individuals. However, when choice is limited emotional signals may suffice to choose the most appropriate behavioural program. So, even if great apes completely lack referential signals that could evolve into words of human language, it is not an obstacle, because referential signals can evolve (and, in fact, they do evolve) from emotional ones. Therefore, even if the earliest signals in hominines were emotional, a well-known evolutionary mechanism would turn them into referential ones.

\section{Decreasing of the Rate of Innateness}

The most important trend in animal communication systems' evolution for the origin of language is a decrease in the rate of innateness in signals. In the 
most primitive communication systems, both signifier and signified are innate. A good example is provided by a male three-spined stickleback. A male stickleback is not aware that its belly becomes red and is unable either to change its colour or to suppress aggressive reaction. Sticklebacks are not very clever, and this mechanism helps them to mate their females and not to let other males mate females instead of them. Natural selection favours those males that attack red-bellied sticklebacks and court silver-bellied ones during the mating period, irrespective of any awareness.

The next stage consists in so-called "hierarchical signals" that have innate form and learned meaning. For example (Fridman, 2013: 8), great spotted woodpeckers (Dendrocopos major) when they defend their territories show their outermost rudders (tail feathers) to their neighbours. Pattern of white spots on the tail feathers is unique for each individual, and the birds recognize their neighbours by sight and remember the results of previous territorial conflicts. That way, when a woodpecker recognizes the neighbouring individual it becomes able to choose its behavioural program based on the information about hierarchical relations between them. In this case, signifier (the pattern of spots) is innate while the signified (information about hierarchical relations) is not.

The next stage consists in so-called ad-hoc-signals (Barulin, 2002). Species having most advanced cognitive abilities, e.g. chimpanzees (Goodall, 1986), can interpret behaviour of conspecifics and are therefore able to turn its elements into signals when it is necessary. In different groups of chimpanzees, different signals are used, which proves cultural transmission (Whiten et al., 1999).

This trend shows how the communication becomes increasingly connected with individual experience and cognition. The human language is the next step in this row: once invented, ad-hoc signals are learned and transmitted culturally.

\section{Human Language as a Communication System Suited for Commenting}

An important tendency in evolution of the communication systems in Primates was revealed by M. A. Deryagina and S. V. Vasiliev (1993): the most ancestral signals denote aggressive intentions, and in more advanced taxa the number and percentage of friendly signals increases (and friendly communicative complexes are formed). It is very important because cooperation plays crucial role in the origin of human language (cf. Tomasello, 2008).

Those aspects of language capacity that are uniquely human combinatorial phonology, derivational and inflectional morphology, hierarchical syntactic structures, compositional semantics, discourse-organizing means, 
speech registers and styles, connotations and so on (see Pinker \& Jackendoff, 2008) - can be carried out only in a communicative system containing a vast (potentially infinite) number of signals (Burlak, 2011: 82). For a communicative system having, say, ten signals, a set of phonological oppositions or a hierarchical syntactic structure is unnecessary.

Therefore, the main line of language emergence was the accumulation of signs, and the main challenge of human evolution was to learn more and more communicative signals. Where does such a challenge come from? The ancestors of ancient hominids were primates with a considerably high intelligence level, able (and willing) to guess reasons, draw conclusions and adopt behavioural patterns (with the help of mirror neurons, see (Arbib, 2012)). During the course of human evolution, these abilities developed - endocasts show the growth of prefrontal cortex in human lineage (Drobyshevskij, 2007). As noted by S. Pinker, language emergence was a part of a complex adaptation to the cognitive niche (Pinker, 2003).

Ecological niche of a savannah big terrestrial omnivorous animal demanded a constant augmentation of number of behavioural patterns and number of observable environmental details useful for guessing reasons and drawing conclusions. For gregarious primates, there was a need to communicate all this to conspecifics. Those who managed to share their findings with their relatives were more efficient in bringing up their offspring. Thus, natural selection favoured the hominid groups whose members were better at sharing knowledge with each other. When hominids learned how to make tools, the number of their behavioural patterns increased, and so did the number of objects and details worth noticing. That way, a means was needed to sort them out, to figure out, which behaviour is best suited to in particular circumstances. Natural selection thus favoured the groups in which a fact known to one individual became known to others easily. When an individual noticed something useful for choosing an optimal behavioural pattern in a situation, and drew his/her relative's attention to this, both would benefit from it. An individual who reported what (s)he saw or heard to his/her relatives became an additional pair of eyes and ears for each member of the group. Note, that such reports did not need to be either conscious or articulate, they only had to be interpreted by others and to provide them with material allowing to draw appropriate conclusions. Unintentional and inarticulate "signals" may be interpreted as well. The main driving force of the evolution of hominids' communicative system was thus a great need for such reports (Burlak, 2012a). 
People - even now - are instinctively convinced that language is a system for naming: "words" are, first of all, names of things, while "sentences" are, first of all, comments to situations. If a non-linguist is asked to say some "words" in another language, (s)he will most probably come up with some names of objects (not verbs, or adjectives, or particles, or even abstract nouns). When one wants to deal with a "sentence", (s)he will at first consider narrative sentences: The farmer killed the duckling, Colorless green ideas sleep furiously and so on. "Basic word order" of a language is nothing more than the word order normally used in narrative sentences. Naturally, such sentences are far from being the only type of utterances occurring in our everyday speech.

Language is not a thing in itself, psychological experiments show that when people are asked to learn certain sentences, they tend to store in their long-term memory not the sentences they were asked to learn but the conclusions that are based on them (Anderson, 2015: 161-162).

At first, such comments, probably, were like modern children's private (egocentric) speech (Vygotsky, 1986). When a child plays, (s)he is constantly telling him/herself what (s)he sees or hears, does, needs, or is going to do. Although such speech is called private (egocentric), children seem to address it not only to themselves, but also to others: in presence of deaf people or foreigners they tend to play almost silently (ibid.). When a child grows up, egocentrical speech turns into inner speech. Human language, as a whole, probably, also evolved in such a way.

\section{Emergence of an Open Communication System}

When a strong demand for comments arose, the natural selection began to favour the groups consisting of individuals who were effective not only in interpreting comments of conspecifics but also in producing comments clear enough to be understood properly. For these purposes, it is optimal to know more signals. So natural selection favoured the groups in which the offspring was willing to know names of all the things in the world.

First signals were certainly iconic, because they had to be understood without any previous knowledge, but after some repetitions, when a signal became known to several members of a group, it could lose its iconicity (as a result of habituation) and become a symbol. In such symbols, distinctive features were singled out, which could be used to distinguish one symbol from another. This rendered it possible to learn new signals very quickly. When multiple signals exist, associations emerge between them, because a word having a meaning activates a neuron assembly, and some of its neurons also 
participate in coalitions corresponding to other meanings; these meanings become associated with each other. This provided the communicative system with an additional function: the one to tell about objects and situations that are beyond the speaker's immediate experience.

When many signals are known, it became possible to invent new signs not on the base of a specific real situation but on the base of previously known signs by means of modifying them. Signs can be modified in any possible way: by adding vocalization to a gesture, or by adding new sounds to a vocalization, by changing the intonation, by performing a given gesture with the other hand, etc. When several pairs of signs and their modified variants became known to the members of a hominid group, they gained the possibility to generalize modifications. That was, obviously, a crucial point of the language evolution because it made the entire communicative system constructable: an individual who knew a few signals and several modification rules became able to produce a great number of new understandable utterances.

The need for comments was also a driving force of switching from gestures to a sound communication system. When the main goal of communication is to make a certain conspecific do something, a communication system can be based on gestures: an individual would approach a conspecific and begin to communicate. But when a communication system is designed to share attention with conspecifics (Tomasello, 2008), it will inevitably become acoustic: an individual ceasing his/her activity to begin a communication would stop perceiving the things (s)he needs to communicate.

For an acoustic communication system with an infinite number of potential utterances, a complex of features is needed. The most relevant features for articulate speech are lowered larynx and increased spinal canal width (indicating the increased capacity of breath control). Another feature of great importance is the lack of air sacs (Boer, 2011). When articulated speech arose, hearing abilities must have increased (chimpanzees have a lower ability to hear high frequency sounds (see Martínez et al., 2008)). The full complex of adaptations for articulated speech appears first in Homo heidelbergensis: this species lacked air sacs, had a wider spinal canal and bigger brain, and maintained a relatively high sensitivity from $2 \mathrm{kHz}$ up to $4 \mathrm{kHz}$ (an interval that contains acoustic features that can be modified by articulation), which renders it highly probable that Homo heidelbergensis was capable of articulated speech (Burlak, 2012b, Dediu \& Levinson, 2013). However, there is no reason to believe that this species had a full-fledged human language, because many aspects of the latter 
are closely associated with frontal lobes, which are smaller in Homo heidelbergensis than in Homo sapiens.

Thus, the increasing demand for incoming information formed a communication system with a potentially endless number of possible utterances. In turn, this created a demand for phonology, syntax and other language-specific features. Focusing on signal interpretation makes it possible not only to solve the problem of honest communication emergence and the problem of gradual change but also to construct a consistent model of language origin.

\section{References}

Anderson, J. R. (2015). Cognitive psychology and its implications ( $8^{\text {th }}$ ed.). New York: Worth Publishers.

Arbib, M. A. (2012) Mirror systems: Evolving imitation and the bridge from praxis to language. In M. Tallerman and K. R. Gibson (Eds.) The Oxford Handbook of Language Evolution (pp. 207-215). Oxford: Oxford Univ. Press.

Barulin, A. N. (2002). Osnovanija semiotiki: znaki, znakovyje sistemy, kommunikatsija. Part 1. Moscow: Sport i kul'tura - 2000. (Foundations of the semiotics: Signs, sign systems, communication.)

Bickerton, D. 2003. Symbol and structure: A comprehensive framework for language evolution. In M. H. Christiansen and S. Kirby (Eds.), Language evolution (pp. 77-93). Oxford: Oxford University Press.

Bickerton, D. (2009). Adam's tongue: how humans made language, how language made humans. New York: Farrar, Straus and Giroux.

Bergman, T. J. (2013). Speech-like vocalized lip-smacking in geladas Current biology, 23(7), R268-R269.

Blumstein, D. T. (2007) The evolution, function, and meaning of marmot alarm communication. Advances in the Study of Behavior, 37, 371-400.

Boer, B. de (2011). Loss of air sacs improved hominin speech abilities. Journal of Human Evolution, 62(1), 1-6.

Burlak, S. A. (2011). Proiskhozhdenije jazyka: Fakty, issledovanija, gipotezy. Moscow: CORPUS. (The origin of language: Facts, research, hypotheses.)

Burlak, S. A. (2012a). Chelovecheskij jazyk kak kommunikativnaja sistemakommentarij Vestnik Rossijskogo Gosudarstvennogo gumanitarnogo universiteta, 88, 132-145. (Human language as a communicative system for commenting.)

Burlak, S. A. (2012b). Vremya pojavlenija zvuchashchej rechi po dannym antropologii. Vestnik Moskovskogo gosudarstvennogo universiteta, Ser. 23 Antropologija, 3, 109-119. (When did articulate speech arise (according to anthropological data)?) 
Cheney, D. L., \& Seyfarth, R. M. (1990). How monkeys see the world. Chicago and London: University of Chicago Press.

Chomsky, N. (2002). On nature and language. Cambridge, England: Cambridge University Press.

Deacon, T. (1998). The symbolic species: The co-evolution of language and the human brain. London: Penguin Books.

Dediu, D., \& Levinson, S. C. (2013). On the antiquity of language: The reinterpretation of Neandertal linguistic capacities and its consequences. Frontiers in Psychology, 4, 397.

Deryagina, M. A., \& Vasil'jev, S. V. (1993). Formy obshchenija u primatov i proiskhozhdenije chelovecheskogo jazyka. In O. A. Donskikh (Fd.) Jazyk $v$ okeane jazykov (pp. 60-85). Novosibirsk: Sibirskij khronograf. (Communication forms in Primates and human language origin.)

Drobyshevskij, S. V. (2007). Evolutsija mozga cheloveka: Analiz Endocraniometricheskikh Priznakov gominid. Moscow: URSS. (The evolution of human brain: an analysis of endocast-measurment features of hominines.)

Evans, Ch. S., \& Evans, L. (1999). Chicken food calls are functionally referential. Animal behaviour, 58(2), 307-319.

Fitch, W. T. (2010). The evolution of language. Cambridge: Cambridge Univ. Press.

Fridman, V. S. (2013). Ot stimula $k$ simvolu: Signaly $v$ kommunikatsii pozvonochnykh. Part 2: Znak v kommunikatsii zhivotnykh. Evolutsija sistem signalizatsii pozvonochnykh. Metodologija analiza signal'nykh sistem. Moscow: Knizhnyj dom "LIBROKOM". (From stimulus to symbol: signals in vertebrates' communication. Part 2: Sign in animal communication. Evolution of signaling systems in vertebrates. Methodology of signaling systems' analysis.)

Gibson, K. R. (2010). Talking about birds, bees, and primates, too. Implications for language evolution. In A. D. M. Smith, M. Schouwstra, B. de Boer, \& K. Smith (Eds.) The Evolution of Language. Proceedings of the 8th International Conference (EVOLANG8), Utrecht (pp. 153-159). London: World Scientific.

Goodall, J. (1986). The chimpanzees of Gombe: Patterns of behavior. Cambridge, MA: The Belknap Press of Harvard University Press.

Hauser, M. D. (1996). The evolution of communication. Cambridge, MA: MIT Press.

Hauser, M. D., Chomsky, N., \& Fitch, W. T. (2002). The Faculty of language: What is it, who has it, and how did it evolve? Science, 298, 1569-1579.

Hauser, M. D., Yang, C., Berwick, R. C., Tattersall, I., Ryan, M. J., Watumull, J., Chomsky, N., \& Lewontin, R. C. (2014). The mystery of language evolution. Frontiers in psychology, 5(401), 1-12.

Hockett, Ch. F. (1960). The origin of speech. Scientific American, 203, 89-97. 
Hollén, L. I., \& Manser, M. B. (2006). Ontogeny of alarm call responses in meerkats, Suricata suricatta: the roles of age, sex and nearby conspecifics. Animal behaviour, 72 (6), 1345-1353.

Hurford, J.R. (2012). The Origins of Grammar: Language in the Light of Evolution. Oxford: Oxford University Press.

Leger, D. W., Owings, D. H., \& Gelfand, D. L. (1980). Single-Note Vocalizations of California ground squirrels: Graded signals and situationspecificity of predator and socially evoked calls. Zeitschrift für Tierpsychologie, 52, 227-246.

Macedonia, J. M. (1990). What is communicated in the antipredator calls of lemurs: Evidence from playback experiments with ringtailed and ruffed lemurs. Ethology, 86, 177-190.

Manser, M. B., \& Bell, M. B. (2004). Spatial representation of shelter locations in meerkats Suricata suricatta. Animal behaviour, 68, 151-157.

Markov, A. V., \& Kulikov, A. M. (2006). Gipoteza immunologicheskogo testirovanija partnerov - soglasovannost' razvitija adaptatsij i smeny polovykh predpochtenij Izvestija RAN, Ser. biologicheskaja, 3, 261-274. (A hypothesis about immunological testing of mating partners: coherence of the development of adaptations and change of sexual preferences.)

Martínez, I., Quam, R., Rosa-Zurera, M., Arsuaga, J. L. (2008). Auditory capacities of human fossils: A new approach to the origin of speech. The Journal of the Acoustical Society of America, 123(5), 3606.

Maynard Smith, J., \& Harper, D. G. C. (2003). Animal signals. Oxford: Oxford University Press.

Okanoya, K. (2002). Sexual display as a syntactical vehicle: The evolution of syntax in birdsong and human language through sexual selection. In A. Wray (Ed.), Transition to language (pp. 46-63). Oxford: Oxford University Press.

Pepperberg, I. M. (2012). Evolution of Communication and Language: Insights From Parrots and Songbirds. In M. Tallerman and K. R. Gibson (Eds.) The Oxford Handbook of Language Evolution (pp. 109-119). Oxford: Oxford Univ. Press.

Pereira, M. E., \& Macedonia, J. M. (1991). Ringtailed lemur antipredator calls denote predator class, not response urgency Animal Behaviour, 41, 543-544.

Pinker, S. 2003. Language as an adaptation to the cognitive niche. In M. H. Christiansen and S. Kirby (Eds.), Language evolution (pp. 16-37). Oxford: Oxford University Press.

Pinker, S., \& Jackendoff, R. (2008). The components of language: What's specific to language, and what's specific to humans. In M. H. Christiansen, C. Collins and S. Edelman (Eds), Language Universals (pp. 126-152). Oxford: Oxford University Press.

Promislow, D. E. L., Smith, E. A., \& Pearse, L. (1998). Adult fitness consequences of sexual selection in Drosophila melanogaster. Proceedings of the National Academy of Science, USA, 95(18), 10687-10692. 
Reznikova, Zh. I. (2017). Studying Animal Languages Without Translation: An Insight from Ants. Cham: Springer.

Rogovin, K. A. (1991). Sotsial'noje povedenije kruglogolovok Phrynocephalus helioscopus i Ph. reticulatus (Reptilia, Agamidae) i ikh vzaimootnoshenija v sovmestnykh poselenijakh. Zoologicheskij zhurnal, 70(3), pp. 61-72. (Social behaviour of toadhead agamas Phrynocephalus helioscopus and Ph. reticulatus (Reptilia, Agamidae) and their interrelations in common settlements.)

Scott-Phillips T. C. The evolution of communication and relevance. In A. D. M. Smith, M. Schouwstra, B. de Boer, \& K. Smith (Eds.) The Evolution of Language. Proceedings of the 8th International Conference (EVOLANG8), Utrecht (pp. 489-490). London: World Scientific.

Seyfarth, R. M., \& Cheney, D. L. (2012). Primate social cognition as a precursor to language. In M. Tallerman and K. R. Gibson (Eds.) The Oxford Handbook of Language Evolution (pp. 59-70). Oxford: Oxford Univ. Press.

Shubin, N. (2008). Your Inner Fish: A Journey into the 3.5-Billion-Year History of the Human Body. New York: Pantheon Books.

Slobodchikoff, C. N., Kiriazis, J., Fischer, Ch., \& Creef, E. (1991). Semantic information distinguishing individual predators in the alarm calls of Gunnison's prairie dogs. Animal Behaviour, 42(5), 713-719.

Slobodchikoff, C. N., Paseka, A., \& Verdolin, J. L. (2009). Prairie dog alarm calls encode labels about predator colors. Animal Cognition, 12, 435-439.

Slocombe, K. E.; Zuberbühler, K. (2005). Functionally Referential Communication in a Chimpanzee. Current Biology, 15(19), 1779-1784.

Tomasello, M. (2008). Origin of human communication. Cambridge (Mass.); London: The MIT Press.

Vygotsky, L. S. (1986). Thought and Language. Cambridge (Mass): The MIT Press.

Whiten, A., Goodall, J., McGrew, W. C., Nishida, T., Reynolds, V., Sugiyama, Y., Tutin, C. E. G., Wrangham, R. W., \& Boesch, Ch. (1999). Cultures in chimpanzees. Nature, 399, 682-685. 